\title{
Effect of sinapic acid on 1,2 dimethylhydrazine induced aberrant crypt foci, biotransforming bacterial enzymes and circulatory oxidative stress status in experimental rat colon carcinogenesis
}

\author{
Balaji C, Muthukumaran J, Nalini N \\ Department of Biochemistry and Biotechnology, Faculty of Science, Annamalai University, Annamalainagar, \\ Tamil Nadu, India.nalininam@yahoo.com
}

\begin{abstract}
AIM: This study was aimed to investigate the effect of sinapic acid (SA) on 1,2-dimethylhydrazine (DMH) induced experimental rat colon carcinogenesis.

MATERIALS AND METHODS: Rats were assorted into six groups, group 1 served as control, group 2 received SA (80 mg/kg b.w.) post orally every day until the end of the experimental period of 16 weeks, groups 3-6 rats were injected DMH (20 mg/kg b.w.) subcutaneously once a week for first four weeks. In addition, groups 4-6 rats received different doses of SA (20, 40 and $80 \mathrm{mg} / \mathrm{kg}$ b.w.).

RESULTS: Our results showed that DMH induced rats revealed significantly increased ACF development and multiplicity, which were significantly inhibited on supplementation with SA. Moreover, elevated levels/activities of circulatory oxidative stress markers, faecal and colonic mucosal bacterial enzymes were observed in $\mathrm{DMH}$ exposed rats, which were diminished on supplementation with SA.

CONCLUSION: Overall, our findings revealed that supplementation with SA offers significant protection against $\mathrm{DMH}$ induced rat colon carcinogenesis and the effect of SA at the dose of $40 \mathrm{mg} / \mathrm{kg} \mathrm{b.w}$. was more pronounced as compared to the other two doses (Tab. 5, Fig. 3, Ref. 46). Text in PDF www.elis.sk.

KEY WORDS: colon cancer, sinapic acid, aberrant crypt foci, bacterial enzymes.
\end{abstract}

\section{Introduction}

Colon cancer remains the third most common malignant neoplasm and the second leading cause of cancer related deaths worldwide (1). American Cancer Society has estimated about 103,170 cases of colon and 40,290 cases of rectal cancer in 2012. Dietary habits play an important role in its etiology, which significantly modify the initiation, promotion, and progression stages of this cancer (2). The incidence of colon cancer has been increasing in many developed and developing countries with westernized lifestyle (3). In the Indian population, recent changes in lifestyle and dietary habits may increase the colon cancer incidence in future (4).

The genotoxic chemical 1,2 dimethylhydrazine (DMH) induced colon cancer in rodents is a widely studied experimental model for identifying the chemopreventive potential of phyto-

Department of Biochemistry and Biotechnology, Faculty of Science, Annamalai University, Annamalainagar, Tamil Nadu, India

Address for correspondence: Dr. N. Nalini, Department of Biochemistry and Biotechnology, Faculty of Science, Annamalai University, Annamalainagar-608 002, Tamilnadu, India.

Phone: +91.4144.239141, Fax: +91.4144.238343

Acknowledgement: This study was supported by the University Grants Commission (UGC), New Delhi, India in the form of Research Fellowship (No.F4-1/2006 BSR) in Science for Meritorious Students (RFSMS) Scheme to C. Balaji is gratefully acknowledged. chemicals, which in addition mimics many of the cell kinetics, histopathological and molecular characteristics in humans (5). $\mathrm{DMH}$, a procarcinogen, is metabolized to methylazoxymethanol (MAM) in the liver and enters the colon via bile or blood stream. MAM is subsequently metabolized into the electrophilic methyldiazonium ion, which in turn generates carbonium ion that targets DNA, inducing the formation of methyl adducts with DNA bases, point mutations and micronuclei yielding macroscopically visible neoplasms (6). Oxidative stress is characterized by an increased rate of reactive oxygen species (ROS) generation and decreased antioxidant enzymes. ROS are potentially dangerous due to high redox potential resulting in peroxidation of cell membranes, oxidative DNA damage, mutagenesis and carcinogenesis (7). Erythrocytes are particularly vulnerable to oxidative damage due to the high content of polyunsaturated fatty acids in the membrane and auto-oxidation of haemoglobin within the cell.

Aberrant crypt foci (ACF) are putative pre-neoplastic lesions that appear at an early stage of colon carcinogenesis in the humans and rodents. ACF are monoclonal collections of abnormal crypts, formed by the exposure to carcinogen. It has been exploited as a short term quantitative approach to identify chemopreventive agents for the treatment of colon cancer (8). Intestinal microflora is considered to play an important roles in the pathogenesis of colon cancer (9), as it not only liberates active key intermediates in the metabolism of procarcinogens but also activates tumour promoters in the colon. Moreover, the toxic and genotoxic metabolites liber- 
<smiles>COc1cc(/C=C/C(=O)O)cc(OC)c1O</smiles>

Fig. 1. Structure of SA.

ated by the colonic microflora can bind to the specific intestinal cell surface receptors and affect intracellular signal transduction (10). $\beta$-glucuronidase, $\beta$-glucosidase, $\beta$-galactosidase and several other enzymes are produced by the intestinal microbes, which release potential carcinogenic compounds in the colon.

Chemoprevention is considered as a promising strategy of cancer control and provides a powerful platform to advance scientific understanding of tumour biology. Emerging clinical and experimental evidence now supports the identification of phytochemicals with the potential to inhibit the processes of carcinogenesis. Sinapic acid (SA) is a phenolic acid and a natural hydrophilic antioxidant which occurs in fruits, vegetables, oil seeds, spices and herbs (11) (Fig. 1). It belongs to the derivatives of hydroxycinnamic acid and constitutes $73 \%$ of free phenolic acid in rapeseed meal. It is a phenylpropanoid compound which possesses 3,5-dimethoxyl and 4-hydroxyl substitutions in the phenyl group of cinnamic acid. Studies have shown SA exhibits several biological activities including anti-inflammatory (12), antioxidant and free radical scavenging (13) effects. The present study was aimed to evaluate the modulatory effect of sinapic acid on 1,2 dimethylhydrazine induced rat colon carcinogenesis.

\section{Materials and methods}

\section{Chemicals}

Sinapic acid (SA) and 1,2 dimethylhydrazine (DMH) were purchased from Sigma Chemical Co., St. Louis, MO, USA. All other chemicals and reagents used were of analytical grade purchased from HiMedia Private Limited, Mumbai. India.

\section{Animals}

Male albino Wistar rats weighing 120-130 g (5 years old) were procured from the Central Animal House of Rajah Muthiah Medical College, Annamalai University, Annamalainagar, Tamilnadu, India. Animals were housed in polypropylene cages with bedding in a specific-pathogen free animal room under controlled environmental conditions of temperature $27 \pm 2{ }^{\circ} \mathrm{C}$, with $50 \pm 10$ $\%$ humidity and $12-\mathrm{h} \mathrm{light/dark} \mathrm{cycle.} \mathrm{The} \mathrm{animals} \mathrm{were} \mathrm{allowed}$ to acclimatize for 1 week before starting the experiments and had free access to modified pellet diet (commercial pellet diet containing $42 \mathrm{~g}$ fat $/ \mathrm{kg}$ was powdered and mixed with $158 \mathrm{~g}$ of peanut oil per kilogram of feed, making a total of $20 \%$ fat in modified pellet diet) and water. The experimental design was approved by the Ethical Committee of Annamalai University in accordance with the Indian National Law on animal care and use (Reg. No. 160/1999/ CPCSEA, Vide No.927, 2012).

\section{Induction of colon carcinogenesis}

DMH (20 mg/kg b.w.) was weighed and dissolved in distilled water containing $1 \mathrm{mM}$ EDTA to ensure the stability of the chemical just prior to use and the $\mathrm{pH}$ was adjusted to 6.5 with 1 $\mathrm{mM} \mathrm{NaOH}$. The animals received DMH injections once a week subcutaneously for the first 4 consecutive weeks of the 16 week experimental period.

\section{Experimental design}

The rats were randomly divided into six groups of twelve animals each. SA was suspended in $0.3 \%$ carboxymethyl cellulose $(\mathrm{CMC})$ and each rat received one of the the daily doses of 20,40 or $80 \mathrm{mg} / \mathrm{kg}$ b.w. SA was administered orally by intragastric intubation every day throughout the experimental period of 16 weeks.

Group 1: Normal control rats

Group 2: Rats received SA ( $80 \mathrm{mg} / \mathrm{kg}$ b.w. post orally) everyday throughout the experimental period

Group 3: Rats received DMH (20 mg/kg b.w. subcutaneously) once a week for the first 4 weeks of the experiment (4 injections)

Group 4: Rats received DMH as in group 3 and SA $(20 \mathrm{mg} / \mathrm{kg}$ b.w. post orally) every day for the entire study period of 16 weeks

Group 5: Rats received DMH as in group 3 and SA $(40 \mathrm{mg} / \mathrm{kg}$ b.w.post orally) every day for the entire study period of 16 weeks

Group 6: Rats received DMH as in group 3 and SA $(80 \mathrm{mg} / \mathrm{kg}$ b.w.post orally) every day for the entire study period of 16 weeks

At the end of the experimental period, rats fasted overnight and sacrificed by cervical decapitation.

\section{Determination of aberrant crypt foci (ACF)}

The rat colon was removed, flushed with cold saline $(0.9 \%$ $\mathrm{NaCl})$ and cut open along the longitudinal median from anus to caecum. It was divided into two segments (proximal and distal), placed on the filter paper with mucosal surface up, fixed flat in $10 \%$ buffered formalin for 24 hours, stained with $0.2 \%$ methylene blue solution and was then placed on the microscopic slide and observed under a light microscope (14). Crypt multiplicity was determined as the number of crypts in each focus and was categorized as containing 1, 2, 3 or more than 3 aberrant crypts/foci.

\section{Biochemical estimations}

Assay of the activities of faecal and mucosal bacterial enzymes

Fresh faecal pellets were collected for the assay of faecal bacterial enzymes. The mucosa from the colon was collected by scraping with a slide. The faecal pellets and colonic mucosa were homogenized using phosphate-buffered saline, centrifuged at $2000 \mathrm{~g}$ for $10 \mathrm{~min}$ at $4{ }^{\circ} \mathrm{C}$ and the supernatant was collected for the assay of the activity of faecal and colonic mucosal bacterial enzymes.

$\beta$-glucuronidase, $\beta$-glucosidase and $\beta$-galactosidase activities were measured by the method of Freeman (15). Nitroreductase activity was measured by the method of Bratton \& Marshal (16). Sulphatase activity was measured by the method of Rowland et al (17). Mucinase activity was measured by the method of Shiau and 
Tab. 1. Effect of SA and DMH on aberrant crypt foci (ACF) in the colon of the control and experimental rats.

\begin{tabular}{|c|c|c|c|c|c|c|}
\hline \multirow{2}{*}{ Group } & \multirow{2}{*}{ No of rats bearing ACF } & \multirow{2}{*}{ Number of ACF } & \multirow{2}{*}{ Number of AC } & \multicolumn{3}{|c|}{ Number of foci containing } \\
\hline & & & & 1 crypt & 2 crypts & $>4$ crypts \\
\hline $\mathrm{I}$ & $6 / 0$ & Nill & Nill & Nill & Nill & Nill \\
\hline II & $6 / 0$ & Nill & Nill & Nill & Nill & Nill \\
\hline III & $6 / 6(100)$ & $58.83 \pm 2.63^{\mathrm{a}}$ & $165.83 \pm 3.48^{\mathrm{a}}$ & $19.16 \pm 1.32^{\mathrm{a}}$ & $19.16 \pm 1.72^{\mathrm{a}}$ & $20.50 \pm 3.72^{\mathrm{a}}$ \\
\hline IV & $6 / 6(100)$ & $39.83 \pm 1.47^{\mathrm{b}}$ & $100.16 \pm 4.0^{\mathrm{b}}$ & $16.50 \pm 1.04^{\mathrm{b}}$ & $15.00 \pm 0.89^{\mathrm{b}}$ & $8.33 \pm 1.03^{\mathrm{b}}$ \\
\hline $\mathrm{V}$ & $6 / 6(100)$ & $20.33 \pm 1.75^{\mathrm{c}}$ & $28.33 \pm 3.07^{\mathrm{c}}$ & $12.00 \pm 0.89^{\mathrm{c}}$ & $8.16 \pm 1.16^{\mathrm{c}}$ & - \\
\hline VI & $6 / 6(100)$ & $29.00 \pm 1.41^{\mathrm{d}}$ & $40.50 \pm 3.27^{\mathrm{d}}$ & $13.83 \pm 2.78^{\mathrm{c}}$ & $9.66 \pm 0.51^{\mathrm{d}}$ & $5.50 \pm 2.58^{c}$ \\
\hline
\end{tabular}

Data are presented as the means \pm S.D. of six rats in each group. Values not sharing a common superscript letter ${ }^{(a-d)}$ differ significantly at $\mathrm{p}<0.05$ (DMRT).

Tab. 2. Distribution of ACF in the colon of experimental rats.

\begin{tabular}{|c|c|c|c|c|c|}
\hline Group & Number of ACF & Proximal colon & Distal colon & Incidence of ACF \% & Inhibition of ACF \% \\
\hline III & $58.83 \pm 2.63^{\mathrm{a}}$ & $22.00 \pm 1.41^{\mathrm{a}}$ & $36.83 \pm 1.47^{\mathrm{a}}$ & 100 & 0 \\
\hline IV & $39.83 \pm 1.47^{\mathrm{b}}$ & $17.00 \pm 1.09^{\mathrm{b}}$ & $22.83 \pm 1.16^{\mathrm{b}}$ & 67.70 & 32.3 \\
\hline $\mathrm{V}$ & $20.33 \pm 1.75^{c}$ & $6.16 \pm 1.47^{\mathrm{c}}$ & $14.16 \pm 1.47^{c}$ & 34.55 & 65.45 \\
\hline VI & $29.00 \pm 1.41^{\mathrm{d}}$ & $9.83 \pm 1.72^{\mathrm{d}}$ & $19.16 \pm 0.75^{\mathrm{d}}$ & 49.29 & 50.71 \\
\hline
\end{tabular}

Data are presented as the means \pm S.D. of six rats in each group. Values not sharing a common superscript letter ${ }^{\text {(a-d) }}$ differ significantly at $\mathrm{p}<0.05$ (DMRT).

Chang (18). The amount of reducing sugar released was measured using the Nelson-Somoyogi Method (19).

Combined alcain blue-periodic acid Schiff (AB-PAS) analysis of colonic mucin

Histochemical analysis of mucin was carried out by combined AB-PAS technique (20). To determine whether DMH caused morphological changes in the mucus cell number and integrity, alcian blue-positive cells were quantified for each category of control and experimental groups of rats.

\section{Preparation of haemolysate}

Blood was collected in heparinized tubes and plasma was separated by centrifugation at $2000 \mathrm{~g}$ for $10 \mathrm{~min}$. After the separation of plasma, the buffy coat was removed and the packed red blood cells (RBCs) were washed thrice with cold physiological saline. To determine the activity of antioxidant enzymes, RBC lysate was prepared by lysing a known volume of RBCs with hypotonic phosphate buffer, $\mathrm{pH}$ 7.4. Centrifugation at $3000 \mathrm{~g}$ for $10 \mathrm{~min}$ at $2{ }^{\circ} \mathrm{C}$ separated the heamolysate.

Estimation of circulatory lipid peroxidation, enzymatic and nonenzymatic antioxidants

Lipid peroxidation (LPO) was estimated spectrophotometrically by measuring the level of thiobarbituric acid reactive substances (TBARS) by the method of Yagi (21) in the plasma and Donnan
(22) in the erythrocyte lysate. Conjugated dienes (CD) were measured by the method of Ohkawa (23). The activity of superoxide dismutase (SOD, EC 1.15.1.1) was assayed by the method of Kakkar et al (24) and that of catalase (CAT, EC 1.11.1.6) by the method of Sinha (25). Reduced glutathione (GSH), glutathione peroxidase (GPx, EC.1.11.1.9) and glutathione reductase (GR, E.C.1.6.4.2) levels/activities were measured by the methods of Ellman (26), Rotruck et al (27), and Carlberg and Mannervik (28) respectively.

\section{Estimation of protein}

Total protein concentration was determined by the method of Lowry et al (29) using bovine serum albumin (BSA) as standard at $660 \mathrm{~nm}$.

\section{Statistical analysis}

Data were analyzed by one-way analysis of variance (ANOVA) and a significant differences among treatment groups were evaluated by Duncan's Multiple Range Test (DMRT). The results were considered statistically significant at $\mathrm{p}<0.05$. All statistical analyses were made using SPSS 17.0 software package (SPSS, Tokyo, Japan).

\section{Results}

Effect of SA and DMH on ACF formation and crypt multiplicity

The effect of SA and DMH on the ACF occurrence, crypt multiplicity and distribution of ACF are shown in Tables 1 and 2,

Tab. 3. Effect of SA and DMH on the faecal bacterial enzymes of the control and experimental rats.

\begin{tabular}{|c|c|c|c|c|c|c|}
\hline Group & $\begin{array}{c}\begin{array}{c}\beta \text {-Glucuronidase } \\
\text { (mg of p-nitrophenol } \\
\text { liberated/min/g protein) }\end{array} \\
\end{array}$ & $\begin{array}{c}\beta \text {-Glucosidase } \\
\text { (mg of p-nitrophenol } \\
\text { liberated/min/g protein) }\end{array}$ & $\begin{array}{c}\beta \text {-Galactosidase } \\
\text { (mg of p-nitrophenol } \\
\text { liberated/min/g protein) }\end{array}$ & $\begin{array}{l}\text { Nitroreductase ( } \mu \text { moles } \\
\text { of p-amino benzoic acid } \\
\text { liberated/min/g protein) }\end{array}$ & $\begin{array}{c}\text { Sulphatase } \\
\text { ( } \mu \text { mol of p-nitrocatechol } \\
\text { liberated/min/g protein) }\end{array}$ & $\begin{array}{c}\text { Mucinase } \\
\text { (mg of glucose } \\
\text { liberated/min/mg protein) }\end{array}$ \\
\hline I & $19.82 \pm 1.33^{\mathrm{a}}$ & $55.68 \pm 4.64^{\mathrm{a}}$ & $23.19 \pm 2.12^{\mathrm{a}}$ & $15.68 \pm 0.99^{\mathrm{a}}$ & $15.41 \pm 0.81^{\mathrm{a}}$ & $2.76 \pm 0.24^{\mathrm{a}}$ \\
\hline II & $18.42 \pm 0.81^{\mathrm{ab}}$ & $53.29 \pm 1.65^{\mathrm{a}}$ & $20.10 \pm 1.47^{\mathrm{a}}$ & $16.32 \pm 0.83^{\mathrm{a}}$ & $18.41 \pm 0.90^{\mathrm{b}}$ & $2.19 \pm 0.20^{\mathrm{b}}$ \\
\hline III & $29.18 \pm 1.34^{\mathrm{c}}$ & $94.50 \pm 7.19^{b}$ & $57.41 \pm 4.71^{\mathrm{b}}$ & $41.52 \pm 3.87^{\mathrm{b}}$ & $40.51 \pm 2.66^{\mathrm{c}}$ & $3.92 \pm 0.37^{\mathrm{c}}$ \\
\hline IV & $24.85 \pm 2.02^{\mathrm{d}}$ & $80.25 \pm 6.30^{\mathrm{c}}$ & $46.32 \pm 4.06^{\mathrm{c}}$ & $36.37 \pm 3.09^{c}$ & $33.06 \pm 2.12^{\mathrm{d}}$ & $3.52 \pm 0.32^{\mathrm{d}}$ \\
\hline V & $17.56 \pm 0.82^{\mathrm{b}}$ & $53.94 \pm 3.65^{\mathrm{a}}$ & $23.50 \pm 1.82^{\mathrm{a}}$ & $15.72 \pm 1.21^{\mathrm{a}}$ & $19.15 \pm 1.43^{\mathrm{b}}$ & $2.80 \pm 0.21^{\mathrm{a}}$ \\
\hline
\end{tabular}

Data are presented as the means \pm S.D. of six rats in each group. Values not sharing a common superscript letter ${ }^{(a-e)}$ differ significantly at $p<0.05$ (DMRT). 
respectively. Representative photographs showing topographical view of ACF is also illustrated in Figure 2. There was no incidence of ACF observed in the control and SA alone supplemented rats (groups 1-2) while the incidence of ACF as well as crypt multiplicity was $100 \%$ in DMH alone treated rats (group 3). Many of the large ACF with 4 or more crypts were observed in the distal colon than in proximal colon. Supplementation with SA to DMH treated rats (group 4, 5 and 6) significantly reduced the incidence of ACF and its multiplicity in a dose dependent manner as compared to the DMH alone treated rats (group 3). Supplementation with SA showed significantly reduced ACF frequency as compared to group 3 (DMH alone). The inhibition rates were $65.45 \%$ in group 5(40 $\mathrm{mg} / \mathrm{kg}$ b.w.), $50.71 \%$ in group $6(80 \mathrm{mg} / \mathrm{kg}$ b.w. $)$ and $32.3 \%$ in group 4 (20 mg/kg b.w.). More pronounced effect on ACF inhibition and crypt multiplicity was observed in the rats supplemented with SA at the dose of $40 \mathrm{mg} / \mathrm{kg}$ b.w. (group 5).
Effect of SA and DMH on faecal and colonic mucosal bacterial enzyme activities

Tables 3 and 4 represents the activities of faecal and colonic mucosal bacterial enzymes in the control and experimental rats. The activities of $\beta$-glucuronidase, $\beta$-glucosidase, $\beta$-galactosidase, nitroreductase, sulphatase and mucinase were significantly increased in DMH alone treated rats (group 3) as compared to the control rats (group 1). Supplementation with SA at any one of the doses such as 20, 40 and $80 \mathrm{mg} / \mathrm{kg}$ b.w. (groups 4-6) significantly decreased the activities of faecal and colonic mucosal bacterial enzymes and a more pronounced effect was observed in the rats supplemented with $40 \mathrm{mg} / \mathrm{kg}$ b.w. SA (group 5).

\section{Effect of SA and DMH on mucin presenting cells}

Figure 3 shows the AB-PAS stained glycoprotein (mucin) in the mucus secreting cells of the control and experimental rats.

Tab. 4. Effect of SA and DMH on the colonic mucosal bacterial enzymes of the control and experimental rats.

\begin{tabular}{|c|c|c|c|c|c|c|}
\hline Group & $\begin{array}{c}\beta \text {-Glucuronidase } \\
\text { ( } \mu \text { g of } \mathrm{p} \text {-nitrophenol } \\
\text { liberated } / \mathrm{min} / \mathrm{g} \\
\text { protein) }\end{array}$ & $\begin{array}{c}\beta \text {-Glucosidase } \\
\text { ( } \mu \text { g of } \mathrm{p} \text {-nitrophenol } \\
\text { liberated } / \mathrm{min} / \mathrm{g} \\
\text { protein) }\end{array}$ & $\begin{array}{c}\beta \text {-Galactosidase } \\
\text { ( } \mu \text { g of } \mathrm{p} \text {-nitrophenol } \\
\text { liberated } / \mathrm{min} / \mathrm{g} \\
\text { protein) }\end{array}$ & $\begin{array}{c}\text { Nitroreductase } \\
(\mu \mathrm{mol} \text { of } \mathrm{p} \text {-amino } \\
\text { benzoic acid liberated/ } \\
\mathrm{min} / \mathrm{g} \text { protein })\end{array}$ & $\begin{array}{c}\text { Sulphatase } \\
\text { ( } \mu \text { mol of } \mathrm{p} \text {-nitrocatechol } \\
\text { liberated } / \mathrm{min} / \mathrm{g} \\
\text { protein) }\end{array}$ & $\begin{array}{c}\text { Mucinase } \\
\text { (mg of glucose } \\
\text { liberated } / \mathrm{min} / \mathrm{mg} \\
\text { protein) }\end{array}$ \\
\hline $\mathrm{I}$ & $5.80 \pm 0.39^{\mathrm{a}}$ & $18.67 \pm 1.39^{\mathrm{a}}$ & $20.47 \pm 1.28^{\mathrm{a}}$ & $16.42 \pm 1.19^{\mathrm{ab}}$ & $18.32 \pm 1.46^{\mathrm{a}}$ & $3.68 \pm 0.27^{\mathrm{a}}$ \\
\hline II & $5.23 \pm 0.22^{\mathrm{a}}$ & $19.80 \pm 1.27^{\mathrm{a}}$ & $20.49 \pm 1.23^{\mathrm{a}}$ & $14.92 \pm 1.29^{\mathrm{b}}$ & $15.41 \pm 0.81^{\mathrm{b}}$ & $3.29 \pm 0.20^{\mathrm{a}}$ \\
\hline III & $13.92 \pm 1.19^{b}$ & $46.36 \pm 1.87^{b}$ & $49.81 \pm 3.95^{b}$ & $27.41 \pm 2.32^{\mathrm{c}}$ & $36.24 \pm 2.64^{\mathrm{c}}$ & $6.62 \pm 0.47^{b}$ \\
\hline IV & $11.13 \pm 0.09^{\mathrm{c}}$ & $40.37 \pm 2.43^{c}$ & $40.25 \pm 3.16^{\mathrm{c}}$ & $25.02 \pm 1.20^{\mathrm{d}}$ & $27.44 \pm 2.05^{\mathrm{d}}$ & $5.43 \pm 0.38^{c}$ \\
\hline VI & $9.56 \pm 0.85^{\mathrm{d}}$ & $35.61 \pm 3.09^{\mathrm{d}}$ & $35.34 \pm 2.91^{\mathrm{d}}$ & $20.59 \pm 1.55^{\mathrm{e}}$ & $21.49 \pm 1.29^{\mathrm{e}}$ & $4.57 \pm 0.35^{\mathrm{d}}$ \\
\hline
\end{tabular}

Data are presented as the means \pm S.D. of six rats in each group. Values not sharing a common superscript letter ${ }^{(a-e)}$ differ significantly at $\mathrm{p}<0.05$ (DMRT).
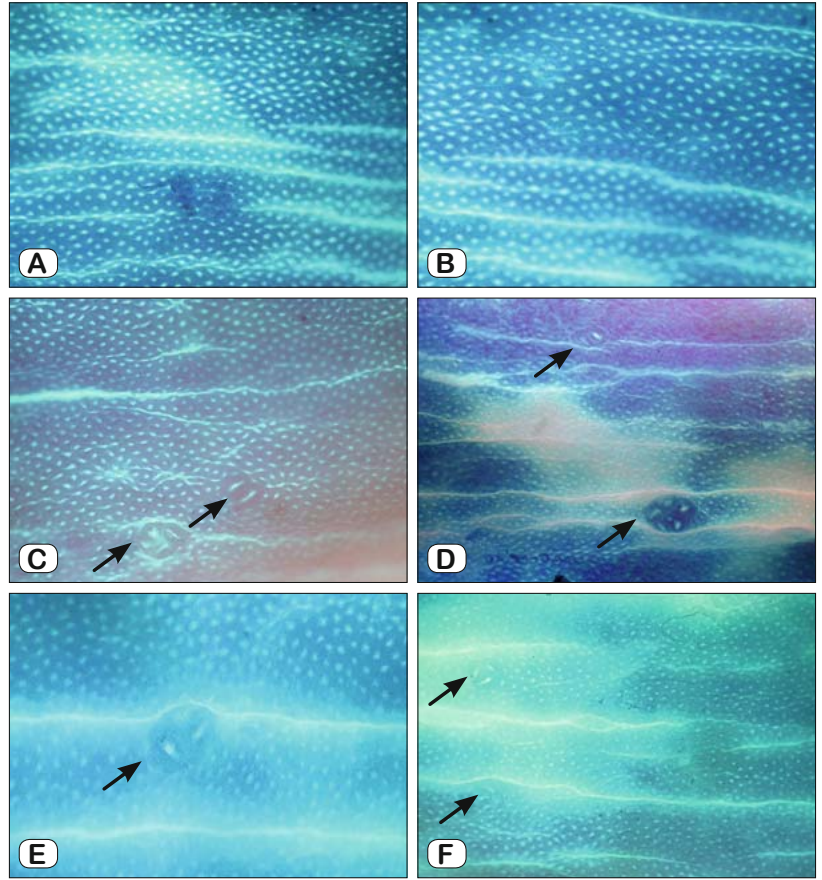

Fig. 2. Topographical view of ACF obtained from (Group I to VI rats) (X20).
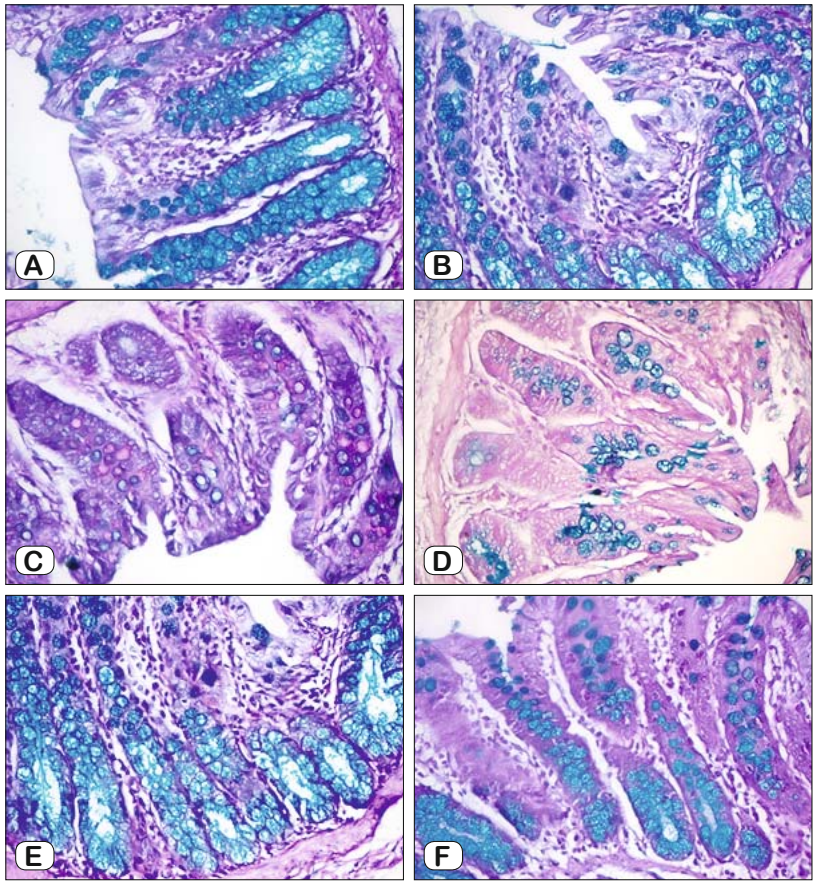

Fig. 3. Cross section of rat colon (Group I to VI) stained with AB-PAS for mucin in the goblet cells (X40). 
Tab. 5. Effect of SA and DMH on circulatory antioxidants and LPO of control and experimental rats.

\begin{tabular}{|c|c|c|c|c|c|c|}
\hline \multirow{2}{*}{ Parameter } & \multicolumn{6}{|c|}{ Group } \\
\hline & $\mathrm{I}$ & II & III & IV & $\mathrm{V}$ & VI \\
\hline Plasma TBARS (nmol/ml) & $1.85 \pm 0.12^{\mathrm{a}}$ & $1.70 \pm 0.16^{\mathrm{a}}$ & $5.01 \pm 0.45^{\mathrm{b}}$ & $4.22 \pm 0.38^{\mathrm{c}}$ & $2.04 \pm 0.19^{\mathrm{a}}$ & $3.59 \pm 0.30^{\mathrm{d}}$ \\
\hline $\mathrm{CD}(\mu \mathrm{mol} / \mathrm{ml})$ & $0.78 \pm 0.04^{\mathrm{a}}$ & $0.71 \pm 0.02^{\mathrm{a}}$ & $1.87 \pm 0.15^{\mathrm{b}}$ & $1.23 \pm 0.08^{\mathrm{c}}$ & $0.82 \pm 0.05^{\mathrm{a}}$ & $1.58 \pm 0.12^{\mathrm{d}}$ \\
\hline Erythrocytes TBARS (pmol/mg Hb) & $1.72 \pm 0.11^{\mathrm{ab}}$ & $1.65 \pm 0.14^{\mathrm{b}}$ & $4.85 \pm 0.25^{\mathrm{c}}$ & $3.50 \pm 0.21^{\mathrm{d}}$ & $1.95 \pm 0.17^{\mathrm{a}}$ & $3.10 \pm 0.27^{\mathrm{e}}$ \\
\hline $\mathrm{SOD}(50 \% \mathrm{NBT}$ reduced/min/mg Hb) & $3.56 \pm 0.23^{\mathrm{a}}$ & $3.6 \pm 0.30^{\mathrm{a}}$ & $1.69 \pm 0.09^{\mathrm{b}}$ & $2.41 \pm 0.17^{\mathrm{c}}$ & $3.83 \pm 0.32^{\mathrm{a}}$ & $3.1 \pm 0.24^{\mathrm{d}}$ \\
\hline CAT $\left(\mu\right.$ moles of $\mathrm{H}_{2} \mathrm{O}_{2}$ utilized $\left./ \mathrm{min} / \mathrm{mg} \mathrm{Hb}\right)$ & $2.67 \pm 0.21^{\mathrm{a}}$ & $2.59 \pm 0.16^{\mathrm{a}}$ & $1.36 \pm 0.07^{\mathrm{b}}$ & $1.65 \pm 0.09^{\mathrm{c}}$ & $2.72 \pm 0.23^{\mathrm{a}}$ & $2.23 \pm 0.18^{\mathrm{d}}$ \\
\hline GPx ( $\mu$ moles of GSH utilized/min/mg Hb) & $29.72 \pm 0.22^{\mathrm{a}}$ & $32.21 \pm 0.25^{\mathrm{b}}$ & $16.53 \pm 0.08^{\mathrm{c}}$ & $21.35 \pm 0.16^{\mathrm{d}}$ & $32.35 \pm 0.21^{\mathrm{b}}$ & $27.86 \pm 0.18^{\mathrm{e}}$ \\
\hline GR $(\mu$ moles of NADPH oxidized/min/mg Hb) & $45.58 \pm 0.44^{\mathrm{a}}$ & $44.52 \pm 0.43^{\mathrm{b}}$ & $38.41 \pm 0.28^{\mathrm{c}}$ & $40.66 \pm 0.37^{\mathrm{d}}$ & $45.51 \pm 0.44^{\mathrm{a}}$ & $42.13 \pm 0.39^{\mathrm{e}}$ \\
\hline $\mathrm{GSH}(\mathrm{mg} / \mathrm{dl} \mathrm{Hb})$ & $34.62 \pm 0.26^{\mathrm{a}}$ & $35.06 \pm 0.30^{\mathrm{b}}$ & $21.72 \pm 0.12^{\mathrm{c}}$ & $24.47 \pm 0.18^{\mathrm{d}}$ & $34.46 \pm 0.23^{\mathrm{a}}$ & $27.31 \pm 0.21^{\mathrm{e}}$ \\
\hline
\end{tabular}

Data are presented as the means \pm S.D. of six rats in each group. Values not sharing a common superscript letter ${ }^{(a-e)}$ differ significantly at $p<0.05$ (DMRT).

The control and SA alone supplemented rats showed strong and intense alcian blue staining (group 1 and group 2). The mucosa of DMH alone treated rats showed faint and weak alcian blue staining, progressive loss of mucin and also a decrease in mucus cell numbers (46/100 cells). The mucosa of DMH treated rats which were supplemented with SA at different doses (group 4-6) showed an increase in the mucus cell staining as well as an obvious increase in the mucus cell size and number (59,83 and 72/ cells) as compared to those found in the mucosa of DMH alone treated rats (group 3)

\section{Effect of SA and DMH on circulatory LPO, enzymatic and non- enzymatic antioxidants}

Levels of LPO by-products in the plasma and erythrocyte lysate are shown in Table 5. The levels of TBARS and CD were significantly elevated in the rats treated with DMH alone (group 3 ) as compared to the control rats (group 1). On supplementing with different doses of SA (20, 40 or $80 \mathrm{mg} / \mathrm{kg}$ b.w.) to DMH treated rats, LPO was significantly decreased as compared to the rats treated with DMH alone.

Table 5 shows the effect of SA on the levels/activities of antioxidants such as SOD, CAT, GPx, GR and GSH in the erythrocyte lysate of the control and experimental rats. DMH alone treated rats (group 3) showed declined activities of SOD, CAT, GPx, GR and GSH as compared to the control rats (group 1). The oxidative stress markers were restored to near normal levels on supplementation with SA at the doses of 20,40 or $80 \mathrm{mg} / \mathrm{kg}$ b.w. to DMH treated rats. A more pronounced effect was observed in the carcinogen treated rats supplemented with $40 \mathrm{mg} / \mathrm{kg}$ b.w. of SA.

\section{Discussion}

DNA adduct formation is the initial step in the process of colon carcinogenesis induced by chemical carcinogens. DMH is an alkylating agent causing point mutation especially at the $\mathrm{O}^{6}$ position of methylguanine $\left(\mathrm{O}^{6}-\mathrm{meG}\right)$ leading to mispair with thymine during DNA replication, resulting in the conversion of a GC pair to AT pair and activation of the k-ras oncogene (30). ACF are heterogenus group of preneoplastic lesions of the adenoma-carcinoma sequence, frequently formed by the mutation of k-ras oncogene. They are characterized by clusters of colonic crypts with abnormal morphology, which initially develop as a single enlarged crypt with a thicker epithelial lining than normal crypts and sub- sequently expand into larger clusters. In the present study, DMH alone treated rats showed large crypts with significantly higher incidence of ACF in the distal colon than in the proximal colon. These results are consistent with the previous findings which also showed greater incidence of colon cancer in the distal colon than the proximal colon (31).

Consumption of high fat diet promotes the risk of colon cancer and increases the number of preneoplastic lesions in the colon (32). Peanut oil is rich in $\omega-6$ fatty acids. $\omega-6$ fatty acids are metabolized to eicosanoids and can act as tumour promoters by virtue of their pro-inflammatory actions and thereby modulate the expression of various oncogenes. In our study, when high fat diet rich in $\omega-6$ polyunsaturated fatty acids (peanut oil) was fed during the carcinogenic stage there was a significant increase in the number and multiplicity of crypts ( $>4$ crypts/focus). Previous studies suggest that ACF are colon cancer precursors, whose size and numbers directly correlate with the risk of developing colon cancer (33). In addition, the crypt multiplicities (crowding of crypts) are more predictive of malignant transformation. Supplementation with three different doses of SA (20, 40 and $80 \mathrm{mg} / \mathrm{kg}$ b.w.) to DMH treated rats suppressed the ACF number, development and its multiplicity. SA at the dose of $40 \mathrm{mg} / \mathrm{kg}$ b.w. showed maximum inhibitory effect $(65.45 \%)$ which could be due to its putative antioxidant and potent chemopreventive properties (34). SA is also known to possess anti-inflammatory activity which could also contribute to its tumour suppressing effects (12).

The intestinal bacteria are known to secrete numerous harmful enzymes by its metabolism resulting in the generation of several genotoxic, mutagenic and carcinogenic substances (35). $\beta$-glucuronidase is an inducible enzyme thought to be responsible for the hydrolysis of methylazoxymethanol (MAM) glucuronide conjugates and releases the toxic carbonium ion which becomes carcinogeneic in the colon. Previous studies demonstrated that elevated activity of $\beta$-glucuronidase may be a primary factor in the etiology of colon cancer with an activation of procarcinogens, carcinogens and mutagens in the colon (36). In our study, we observed DMH alone treated rats showed increased activities of faecal and colonic mucosal $\beta$-glucuronidase, which could be due to the influence of high fat diet on colonic microbiota and bacterial metabolism. On the other hand, supplementation with SA to DMH treated rats decreased the $\beta$-glucuronidase activity thereby reducing the production of MAM in the colon and inhibiting tumour initiation. 
The gut microbial flora is also influenced by other glycolytic enzymes like $\beta$-glucosidase and $\beta$-galactosidase. These glycolytic enzymes are strongly associated with colon carcinogenesis as they modulate the carcinogenic impact of toxic and mutagenic compounds. $\beta$-glucosidase also hydrolyses the conjugated products of detoxification and is involved in the formation of toxic aglycones from plant glucosides (37). Increased activity of $\beta$-galactosidase is encountered in the intestinal tract of mammals, and plays a major role in the metabolic activation of various xenobiotics. Roberton (38) reported that increasing the activities of the DMH retoxifying bacterial enzymes may influence tumour development in the colon. In our study, we observed enhanced $\beta$-glucosidase and $\beta$-galactosidase activities in the faecal and colonic mucosa of $\mathrm{DMH}$ alone treated rats indicating the generation of excess amount of carcinogens from aglycones that lead to the activation of the tumour promoters and putative procarcinogens.

The intestinal bacteria fullfill its energy needs by fermenting various types of substrates resulting in the generation of an extensive number of enzymes like nitroreductase and sulphatase. Nitroreductase is a physiological enzyme which plays a key role in the metabolism of the exogenous nitroaromatic chemicals and the products of these biotransformation can be toxic to the host (39). Sulphatase catalyzes the hydrolysis of sulphate ester bonds of a wide variety of substrates and also assist in the desulphation of conjugated toxins. In our study, DMH treated rats displayed elevated activities of nitroreductase and sulphatase in the faecal contents and colonic mucosa as compared to the controls. Numerous studies have indicated a link between decreased incidence of colon cancer and reduced activities of colonic bacterial enzymes (40). Similarly, in the present study, supplementation with SA revealed decreased activities of bacterial enzymes which could be attributed to the anticarcinogenic property of SA as it reduces the toxins and carcinogens in the colon.

Colonic epithelial cells form a single layer of columnar cells which are interspaced with specialized goblet cells which secrete mucin to form a protective barrier against pathogens and toxins. Mucins are a family of secretory cell surface glycoproteins which play an important role in the mucus layer formation, responsible for specific gel properties to protect and lubricate the epithelium (41). Mucinase is a complex high molecular weight hydrolytic enzyme secreted by gut microflora which hydrolysis the protective mucus layer. In the present study, rats treated with DMH alone showed elevated mucinase activity and depleted mucin content (goblet cells) on staining with Alcian blue-periodic acid Schiff stain (AB-PAS) as compared to the control rats. Enhanced mucinase activity can lead to a shift in the balance between mucin secretion and degradation. In this context, deregulation of mucin production has provided an important link between inflammation and cancer (42). Enhanced degradation of the mucosal lining (mucin) ensures a greater contact of the toxic carcinogen with the colonic epithelial cells (43). Our findings suggest that, supplementation with SA to DMH treated rats decreased the activity of mucinase and enhanced the mucin content in the colon of rats emphasizing the antibacterial effect of SA.
Reactive oxygen species (ROS) have been implicated in both the initiation and promotion stages of carcinogenesis that can cause a wide spectrum of cell damage including lipid peroxidation (LPO), inactivation of enzymes and DNA damage (44). In the present study, tumour bearing rats showed enhanced levels of LPO which may be due to the overproduction of free radicals by procarcinogen $(\mathrm{DMH})$ metabolization. The decreased level/activities of enzymatic and non enzymatic antioxidants in the circulation of DMH alone treated rats may be due to their overutilization to scavenge the products of LPO or due to sequestration by tumour cells. Moreover, tumour cells are known to generate and release large amounts of peroxides into the circulation which can subsequently oxidize GSH present there (45). Depletion of GSH impairs the ability of the cells to protect against the free radicals resulting in enhanced LPO. Hence, elevated levels of LPO increases oxidative stress mediated membrane damage of erythrocytes, due to the depletion of enzymatic and non enzymatic antioxidants such as SOD, CAT, GPx, GR and GSH. Supplementation with SA to DMH treated rats reduced the LPO levels and increased the levels/ activities of antioxidant enzymes alleviating oxidative stress. In this context SA is known to effectively quench superoxides and scavenge the hydroxyl, and peroxyl radicals, thereby reducing oxidative stress and sparing GSH (46).

Conclusively, the results of the present study suggest that SA (40 mg/kg b.w.) protects colonic tissue against DMH induced colon cancer by reducing the preneoplastic lesions, modulating the levels/activities of erythrocyte LPO and antioxidant status and also by ameliorating bacterial enzyme activities.

\section{References}

1. Aisha AF, Abu-Salah KM, Ismail Z, Majid AM. In vitro and in vivo anti-colon cancer effects of Garcinia mangostana xanthones extract. BMC Complement Altern Med 2012; 12: 104.

2. Schorah CJ. Micronutrients, vitamins, and cancer risk. Vitam Horm 1999; 57: 1-23

3. Chapelle A. Genetic predisposition to colorectal cancer. Nat Rev Cancer 2004; 4 (10): 769-780.

4. Ganesh B, Talole SD, Dikshit R. A case-control study on diet and colorectal cancer from Mumbai, India. Cancer Epidemiol 2009; 33 (3-4): 189-193.

5. Jackson PE, O’Connor PJ, Cooper DP, Margison GP, Povey AC. Associations between tissue-specific DNA alkylation, DNA repair and cell proliferation in the colon and colon tumour yield in mice treated with 1,2-dimethylhydrazine. Carcinogenesis 2003; 24 (3): 527-533.

6. Choudhary G, Hansen H. Human health perspective on environmental exposure to hydrazines: a review. Chemosphere 1998; 37 (5): 801-843.

7. Panda K, Chattopadhyay R, Chattopadhyay DJ, Chatterjee IB. Vitamin $\mathrm{C}$ prevents cigarette smoke-induced oxidative damage in vivo. Free Radic Biol Med 2000; 29 (2): 115-124.

8. Alain T, Wong JF, Endersby R et al. Reovirus decreases azoxymethane-induced aberrant crypt foci and colon cancer in a rodent model. Cancer Gene Ther 2007; 14 (10): 867-872.

9. Candela M, Guidotti M, Fabbri A, Brigidi P, Franceschi C, Fiorentini C. Human intestinal microbiota: cross-talk with the host and its potential role in colorectal cancer. Crit Rev Microbiol 2011; 37 (1): 1-14. 


\section{$560-566$}

10. Zhu Q, Gao R, Wu W, Qin $\mathbf{H}$. The role of gut microbiota in the pathogenesis of colorectal cancer. Tumour Biol 2013; 34 (3): 1285-1300.

11. Menezes JC, Kamat SP, Cavaleiro JA, Gaspar A, Garrido J, Borges F. Synthesis and antioxidant activity of long chain alkyl hydroxycinnamates. Eur J Med Chem 2011; 46 (2): 773-777.

12. Yun KJ, Koh DJ, Kim SH et al. Anti-inflammatory effects of sinapic acid through the suppression of inducible nitric oxide synthase, cyclooxygase-2, and proinflammatory cytokines expressions via nuclear factorkappa B inactivation. J Agric Food Chem 2008; 56 (21):10265-10272.

13. Gaspar A, Martins M, Silva P et al. Dietary Phenolic Acids and Derivatives. Evaluation of the Antioxidant Activity of Sinapic Acid and Its Alkyl Esters. J Agric Food Chem 2010; 58: 11273-11280.

14. Bird RP, Good CK. The significance of aberrant crypt foci in understanding the pathogenesis of colon cancer. Toxicol Lett 2000; 112: 395-402.

15. Freeman HJ. Effects of differing purified cellulose, pectin and hemicellulose fiber diets on fecal enzymes in 1,2-dimethylhydrazineinduced rat colon carcinogenesis. Cancer Res 1986; 46 (11): 5529-5532.

16. Bratton AC, Marshall E. A new coupling component for sulfanilamide determination. J Biol Chem 1939; 128: 537-550.

17. Rowland IR, Mallett AK, Wise A. A comparison of the activity of five microbial enzymes in cecal content from rats, mice, and hamsters, and response to dietary pectin. Toxicol Appl Pharmacol 1983; 69 (1): 143-148.

18. Shiau SY, Chang GW. Effects of dietary fiber on fecal mucinase and beta glucuronidase activity in rats. J Nutr 1983; 113 (1): 138-144.

19. Nelson N. A photometric adaptation of the Somogyi method for the determination of glucose. J Biol Chem 1944; 153:375-380.

20. Mowry RW. Observation on the use of sulphuricether for the sulphation of hydroxyl groups in tissue sections. J Histochem Cytochem 1958; 6 (2): 82-83.

21. Yagi K. Lipid peroxides and human disease. Chem Phys Lipids 1987; 45 (2-4): $337-351$.

22. Donnan SK. The thiobarbituricacid test applied to tissues from rats treated in various ways. J Biol Chem 1950; 182: 415-419.

23. Ohkawa H, Ohishi N, Yagi K. Assay for lipid peroxides in animal tissues by thiobarbituric acid reaction. Anal Biochem 1979; 95 (2): 351-358.

24. Kakkar P, Das B, Viswanathan PN. A modified spectrophotometeric assay for superoxide dismutase. Indian J Biochem Biophys 1984; 21 (2): 130-132.

25. Sinha KA. Colorimetric assay of catalase. Anal Biochem 1972; 47 (2): 389-394.

26. Ellman GL. Tissue sulphydryl groups. Arch Biochem Biophys 1959; 82 (1): 70-77.

27. Rotruck JT, Pope AL, Ganther HE, Swanson AB, Hafeman DG, Hoekstra WG. Selenium: Biochemical role as a component of glutathione peroxidase. Science 1973; 179 (4073): 588-590.

28. Carlberg I, Mannervik B. Glutathione reductase. Methods Enzymol 1985; 113: 484-490.
29. Lowry OH, Rosebrough NJ, Farr AL, Randall RJ. Protein measurement with the folin phenol reagent. J Biol Chem 1951; 193 (1): 265-275.

30. Zalidi NH, Pretlow TP, O’Riordan MA, Dumenco LL Allay E, Gerson SL. Transgenic expression of human MGMT protects against azoxymethane-induced aberrant crypt foci and $\mathrm{G}$ to A mutations in the K-ras oncogene of mouse colon. Carcinogenesis 1995; 16 (3): 451-456.

31. Liu R, Xu G. Effects of resistant starch on colonic preneoplastic aberrant crypt foci in rats. Food Chem Toxicol 2008; 46 (8): 2672-2679.

32. Cowey SL, Quast M, Belalcazar LM et al. Abdominal obesity, insulin resistance, and colon carcinogenesis are increased in mutant mice lacking gastrin gene expression. Cancer 2005; 103 (12): 2643-2653.

33. Wargovich JM, Brown RV, Morris J. Aberrant Crypt Foci: The Case for Inclusion as a Biomarker for Colon Cancer. Cancers (Basel) 2010; 2 (3): $1705-1716$

34. Balaji C, Muthukumaran J, Nalini N. Chemopreventive effect of sinapic acid on 1, 2-dimethylhydrazine induced experimental rat colon carcinogenesis. Hum Exp Toxicol 2014; 1-16.

35. O'Keefe SJ. Nutrition and colonic health: the critical role of the microbiota. Curr Opin Gastroenterol 2008; 24 (1): 51-58

36. Kim DH, Jin YH. Intestinal bacterial beta-glucuronidase activity of patients with colon cancer. Arch Pharm Res 2001; 24 (6): 564-567.

37. Pool-Zobel BL, Van Loo J, Rowland I, Roberfroid MB. Experimental evidences on the potential of prebiotic fructans to reduce the risk of colon cancer. Br J Nutr 2002; 87 (2): S273-S281.

38. Roberton AM. Roles of endogenous substances and bacteria in colorectal cancer. Mutat Res 1993; 290 (1): 71-78.

39. Davis CD, Milner JA. Gastrointestinal microflora, food components and colon cancer prevention. J Nutr Biochem 2009; 20 (10): 743-752.

40. Gudiel-Urbano M, Goni I. Effect of edible seaweeds (Undaria pinnatifida and Porphyra ternera) on the metabolic activities of intestinal microflora in rats. Nutri Res 2002; 22 (3): 323-331.

41. Moniaux N, Escande F, Porchet N, Aubart JP, Batra SK. Structural organization and classification of the human mucin genes. Front Biosci 2001; 6: D1192-1206

42. Kufe DW. Mucins in cancer: function, prognosis and therapy. Nat Rev Cancer 2009; 9 (12): 874-885.

43. Sangeetha N, Felix AJ, Nalini N. Silibinin modulates biotransforming microbial enzymes and prevents 1,2-dimethylhydrazine-induced preneoplastic changes in experimental colon cancer. Eur J Cancer Prev 2009; 18 (5): 385-394.

44. Sun Y. Free radicals, antioxidant enzymes and carcinogenesis. Free Radic Biol Med 1990; 8 (6): 583-599.

45. Nishikawa M. Reactive oxygen species in tumor metastasis. Cancer Lett 2008; 266 (1): 53-59.

46. Pari L, Mohamed Jalaludeen A. Protective role of sinapic acid against arsenic: induced toxicity in rats. Chem Biol Interact 2011; 194 (1): 40-47.

Received November 18, 2014. Accepted November 3, 2014. 